\title{
Annular Lesion
}

National Cancer Institute

\section{Source}

National Cancer Institute. Annular Lesion. NCI Thesaurus. Code C111971.

A ring-shaped skin finding with clear central area. 